\title{
Action and Its Result in the Bodhicaryāvatāra
}

\section{Chikō ISHIDA}

I. We have two versions of the Bodhicaryāvatāra: the standard Sanskrit version with ten chapters (abbr. as $B C A$ ), and the Tibetan version from Tun-huang with nine chapters (abbr. as $B C T$ ). According to recent studies we can assume that the $B C T$ had been written earlier than $B C A .{ }^{1)}$ Since Chapter 2 of the $B C T$ is divided into two chapters in the $B C A$ (Chapters 2 and 3), Chapter 8 of the $B C T$, the chapter on Prajñ $\bar{a}$, which I shall take up here, corresponds to Chapter 9 of the $B C A$. The difference between two versions is greatest in this chapter: the $B C T$ has only 90.5 $k \bar{a} r i k \bar{a} s$ whereas the $B C A$ has 168 . As a whole the $B C A$ must have been an extended version of the $B C T$, but there are also 22.5 kārikās which exist only in the $B C T .{ }^{2)}$ Here I discuss some of these kāaikās, BCT 8.40$44 \mathrm{ab}$ and $45-52$, specifically the latter half.

The subject of $B C T$ 8.37-56 and $B C A$ 9.58-78, as a whole, is "the absence of self." And two versions have several kārikās in common: $B C T$ 8.37-39, 44cd, 53 and 55 correspond to $B C A 9.58-60,69 a b, 76$ and 75 respectively ( $B C T 44 \mathrm{~cd}$ and 53 do not fully correspond to $B C A 69 \mathrm{ab}$ and 76 ). The different part which exists only in $B C T$ can be divided into two groups: $B C T$ 8. 40-44ab and 45-52.

In the former part Santideva says that our consciousness must not be our "self." As we know in the $B C A P, B C A$ 9.60-73 criticize "the self" theory of the Naiyāyika, Mimāmsaka and Sāṃkhya schools. ${ }^{3)}$ Among these kārikās $B C A 9.60$ and $69 \mathrm{ab}$ are common with the $B C T$ as mentioned above, and $B C A 9.74$ are closely related to $B C T 40$ and 41 . So it can be said that the subject on $B C T$ 8.40-44ab is enlarged in $B C A 9.61-$ 68 and $69 \mathrm{~cd}-74$. Dr. A. Saito indicates that many of these additions to the $B C A$ including the criticism of İ́vara $(B C A$ 9.119-126) and Sāmkhya's 
(24) Action and Its Result in the Bodhicaryāvatāra (C. ISHIDA)

theory $(65,127-138)$ seem to be unnecessary. ${ }^{4)}$ Hence, no further reference to these parts will be made herein.

In the latter part ( $B C T$ 8.45-52) momentariness of all the entities and also the relation between actions and results are discussed. And that discussion leads to "the absence of self." We can find almost no corresponding $k \bar{a} r i k \bar{a} s$ in the $B C A$ (except for $B C A$ 9.73, which I will refer to later). From here I shall take a closer look at these kārikās.

II. In general Śāntideva is regarded as a successor of Candrakirti, who is a representative of the Prāsangika school. The argument about action and its result is, in principle, based on the theory of Mādhyamika, whose ultimate truth is "Any entity can never come into existence from oneself, from others, from both or from lack of causes." ( $M K$ 1.1.) This understanding is common to both of Sāntideva and Candrakirti. But as far as their understanding of action and its result is concerned, there seems to be some difference between them. More precisely, their view on the truth for a yogi or a contemplative saint seems different.

I will begin with the following three kārikās: ${ }^{5)}$

It is not to be supposed that any body and the like which have already arisen will arise. If therefore an action and its result exist also in such [permanent body and the like], why can one not suppose these (an action and its result) also in vacuity? ( $B C T$ 8.45)

Some parts which exist in a seed appear in the stage of fruit. So even if the body and the like might be momentary, why can one not suppose an action and its result be there? ( $B C T$ 8.46)

Just as tuberculosis or poison of mice has struck a child's body, and a temper [arises] in an old man, why can't one similarly suppose an action and its result [exist]? (BCT 8.47)

In $\mathrm{k}^{\circ} 45$ the author denies self-causation just as in the $M A v$ Candrakirti criticized the theory of self-causation of the Sāmkhya school, and so on. ${ }^{6)}$ The BCTP says, "Even if you admit the existence of the permanent self, since it is eternal you cannot suppose that it has action and its result. [And so you cannot assume the permanent self.]"7) And "in order to explain that even if 'the self' does not exist, action and its result don't 
contradict momentary entities," ${ }^{8)}$ Śāntideva gives the seed and fruit example $\left(\mathrm{k}^{\circ} 46\right)$ and the sickness example $\left(\mathrm{k}^{\circ} 47\right)$.

$\mathrm{K}^{\circ} 46$ deals with momentariness and causality. As $B C A(P)$ suggests, ordinary people are not able to understand momentariness (that every entity arises and diseppears momentarily) and only yogis can recognize it. ${ }^{9}$ As indicated in a previous articel, ${ }^{10}$ the way by which one determines differences of the two truths depends on the perceiver; i.e., ordinary people see all entities as truth whereas a yogi regards all as illusions. And yogis are classified into many stages from the bottom up to the top according to their wisdom. Consequently, the above-mentioned Sāntideva's argument on momentariness and causality does not pertain to ordinary people, but to a yogi, who is on the way to ultimate truth.

On the other hand, Candrakiri denies in the $M A v$ the arising of entities from themselves, from others, from both of these or from lack of causes. ${ }^{11}$ And he says, "Ordinary people, without making a close examination (vicära) such as '[all entities come into existence] from themselves, from others, .....,' just think 'from a cause, an effect arises." 12) “A close examination" in this passage is, as Dr. Ejima pointed out, of a yogi. ${ }^{13)}$ Therefore, in the $B C T$ Sanntideva is referring to a causality on a yogi's level while Candrakirti is not.

III. In $\mathrm{k}^{\circ} 46 \mathrm{I}$ think the author assumes that something which connects action and its result corresponds to "some part in seed." And in $\mathrm{k}^{\circ} 47$ when yon consider the poison of mice and getting sick as action and its result, you must think of the child's body as that which connects the poison to the disease. And Sāntideva says that such human bodies are momentary in kārikēs $48-50$. And he concludes by $\mathrm{k}^{\circ} 52$ :

This shows no being can exist, and these entities are momentary. Unmoved things arise from unmoved things and disappear. ${ }^{14}$

The BCTP comments upon this: "In order to explain that [all things] arise from each series ( $r g y u d$ ) which does not exist [as an eternal being] and disappears, ...." ${ }^{15)}$ Here we can find the idea of a series (rgyud) which connects an action and its result. Of course we must keep in mind his 
( 26 ) Action and Its Result in the Bodhicaryāvatāra (C. ISHIDA)

standpoint as Mādhyamika: Why can you say things really exist only because there is a series (rgyun) for a long time? (BCT 8.9ab) ${ }^{16)}$ So we might say Śantideva accepts the idea of a series which connects an action and its result at a yogi's level.

I will point out $B C A 9.73$ here:

If one says that what is having cause is united with the effect, this union is never seen. [Buddha] taught that the doer is the recipient recourse to a unity of a series (samtāna).

As ultimate truth, the relation between cause and effect can not be acceptable to Sāntideva as well, but he follows the ordinary apprehension in a way to regard many continuous moments as unity. ${ }^{17)}$ And in this case a series is required. On this $k \bar{a} r i k \bar{a}$ the $B C A P$ introduces a lot of arguments somewhat marshalling theories of other schools. Therefore the $B C A P$ must be read very carefully. Now I would like to point out that in the $B C A P$ Prajñākaramati explains the relation of an action and its result with the theory of "special evolution of its series" (samptatiparinamaviśeșa). ${ }^{18)}$ We can find the same theory in the Abhidharmakośabhāṣya ${ }^{19)}$, the Karmasiddhiprakarana ${ }^{20)}$ and several other works. The theory is ascribed to the Sautrāntika school. ${ }^{21)}$ The exposition in the $B C A P$ is somewhat over-influenced by this theory.

Nevertheless, we can find at least this similarlity between the series idea in the $B C T$, especially in the seed and fruit example of $\mathrm{k}^{\circ} 46$ and simple series (saṃtāna) theory ascribed to Sautrāntika which is also referred to in the $M K$ as follows: ${ }^{22)}$

A series beginning in a sprout comes forth from a seed and fruit comes forth from it (sprout). Without a seed that [series] does not comes forth. ( $M K$ 17.7) Since the series comes forth from a seed and fruit arises from the series, and the fruit is preceded by the seed, therefore there is no interruption and no eternity. ( $M K$ 17.8)

Here we can certainly find a close relationship between the theory of the Sautrāntikas' and Sāntideva's idea about the seed and fruit example and the series theory. 
IV. In $B C T 8.45-52$, to which we can find almost no corresponding $k \bar{a} r i k \bar{a} s$ in the $B C A$, Sāntideva admits the relation between action and its result at a yogi's level. What connects action and its result is the idea of the series (samtāna), and the idea in the $B C T$ seems to be closely related to the Sautrāntika theory.

〈Texts and Abbreviations〉 $B C A(P)$ : Bodhicaryāvatāra (-pañjikā), ed. L. de la Vallée Poussin, Calcutta 1901-14; BCT: Bodhisattvacaryāvatāra, Stein Tibetan (:ST) no. 628, see Saito (1993); BCTP: ${ }^{\circ}$ vivṛttipañjikā. D 3873 (La), P 5274 (La), sẹe Saito (1993); MAv: Madhyamakāvatāra, ed. L. de la Vallée Poussin, St. Pétersbourg 1907-12; MK: Mūlamadhyamakakārikā; Pras: Prasannapadā, ed. L. de la Vallée Poussin, St. Pétersbourg 1903-13; Saito (1993): A. Saito, A Study of Akṣayamati (S̄āntideva)'s Bodhisattvacaryāvatāra as Found in the Tibetan Manuscripts from Tun-huang, Grant-in-Aid for Scientific Research (C), 1993.

1) A. Saito, 'Śāntideva's Philosophy an Expressed in the Early Version of his Bodhisattva-caryāvatāra, Chapter 8," Tokai Bukkyo, Journal of Tokai Association of Indian and Buddhist Studies 39, 1994 Nagoya, pp. (1)-(17), and two other publications by the same author indicated in notes (3) and (9) of this article; C. Ishida, "The Prātimokṣa and the Deśanā-ritual in the Bodhicaryāvatāra: Some Evidences of its Revision and Retranslation," The Bukkyo Shigaku Kenkyu, The Journal of the History of Buddhism 36-2, Kyoto 1993, pp. (1)-(27) and another paper by the same author indicated in the note (4) of this article.

2) Saito (1993) p. (25). 3) $B C A P$ 452.7-470.15. 4) Saito (1993) pp. 25-26. 5) lus las stsogs pa gyurd kyan ni// gań źig 'gyur bar myi 'dod pa'// de la 'ań las 'bras yod na ni// mkha' la 'an de dag cis myi 'dod//(45) sa bon la ni yod pa'i cha/l 'bras bu'i dus na snañ ba bźin// de bźin lus stsogs myi rtag la 'añ// ci ste las dań 'bras myi 'dod// (46) byis pa'i lus la gcon dań ni// byi ba'i dug ni źend gyurd pa'// rgan la sdañ ba de bźin du// [ci ste]* las dan 'bras myi 'dod//(47)* read as ST 629. 6) MAv 82. 6-83.9. 7) Saito (1993), 79.6-8 (D 346b 2). 8) BCTP, Saito (1993), 79. 9-12 (D 346b 2-3). 9) $B C A P$ 376.6-378.11. 10) C. Ishida, "Ultimate Reality (paramārtha) and Convention (samvṛti) in the Bodhicaryāvatāra: Stages of a Yogin," The Journal of the Nippon Buddhist Research Association 59, 1994, pp. (25) $-(36)$.

11) $M A v$ 82.5-102.11, 113.14-114.14.

12) Pras. 27. 4-5. Y. Ejima, "The Significance of Dialogue in the Mādhyamika School: With Special Reference to Candrakirti," Journal of the History of Buddhist Thought, no.3, Kyoto 1980, pp. 168-173. In the $B C T / B C A$ the idea of vicära is important as well, but no argument will be made here. 14) de ltar sems can 'ga' myed de/l dnos po 'di dag skad cig ma/l gYo ba myed pa'i chos rnams las// gYo ba myed pa'i* 'byun źin 'jig// * read pa as ST 629. 15) Saito (1993), p.79 (D 346b 4-5). 
( 28 ) Action and Its Result in the Bodhicaryāvatāra (C. IsHIDA)

16) rgyun rin tsam gyis ci ltar na/l dnos po bden par yod pa yin/l (cf. $B C A$ 9.10cd) 17) $B C A P$ 471.8-10. 18) $B C A P$ 472.8-473.9. 19) ed. P. Pradhan, Patna 1967, 477.5-478.8. 20) G. Muroji (ed.), The Tibetan Text of the Karmasiddhiprakarana of Vasubandhu with Reference to the Abhidharmakośabhāṣya and the Pratītyasamutpādavyākhyā, Kyoto 1985, p.16, 39. 21) K. Yokoyama, "Seshin no Shiki Tenpen," Koza Daijo Bukkyo 8: Yuishiki Shiso, Tokyo 1982, pp.119-121. 22) cf. Y. Kajiyama, "Bhāvaviveka no Go Shiso," S. Kumoi (ed.), Go Shiso Kenkyu, Kyoto 1979, p.352, n. 17.

〈Key Words〉 Bodhicaryāvatāra, action and its result, saṃtāna

(Lecturer, Kansai University)

NEW PUBLICATION

Jonathan SiLK

The Heart Sutra in Tibetan:

A Critical Edition of the Two Recensions

Contained in the Kanjur

(Wiener Studien zur Tibetologie und Buddhismus Kunde 34)

Vienna: Arbeitskreis für Tibetische und Buddhistische Studien, Universität Wien

October 1994 